\title{
REVIEW
}

\section{Clinical review: Sepsis and septic shock - the potential of gene arrays}

Hector R Wong*

\begin{abstract}
Over the past decade several investigators have applied microarray technology and related bioinformatic approaches to clinical sepsis and septic shock, thus allowing for an assessment of how, or if, this branch of genomic medicine has meaningfully impacted the field of sepsis research. The ability to simultaneously and efficiently measure the steady-state mRNA abundance of thousands of transcripts from a given tissue source (that is,'transcriptomics') has provided an unprecedented opportunity to gain a broader, genomelevel 'picture' of complex and heterogeneous clinical syndromes such as sepsis. A trancriptomic approach to sepsis and septic shock is technically challenging on multiple levels, but nonetheless modest, tangible advances are being realized. These include a genomelevel understanding of the complexity of sepsis and septic shock, identification of novel candidate pathways and targets for potential intervention, discovery of novel, candidate diagnostic and stratification biomarkers, and the ability to stratify patients into clinically relevant, expression-based subclasses. The challenges moving forward include robust validation studies, standardization of technical approaches, standardization and further development of analytical algorithms, and large-scale collaborations.
\end{abstract}

\section{Introduction}

Over the past decade several investigators have applied microarray technology and related bioinformatic approaches to clinical sepsis and septic shock, thus allowing for an assessment of how, or if, this branch of genomic medicine has meaningfully impacted the sepsis field. This review will first provide an overview of the gene

*Correspondence: hector.wong@cchmc.org

Division of Critical Care Medicine, Cincinnati Children's Hospital Medical Center and Cincinnati Children's Hospital Research Foundation, Department of Pediatrics, University of Cincinnati College of Medicine, Cincinnati, OH 45229-3039, USA microarray approach, including limitations and study design considerations. Subsequently, the review will focus on the potential translational application of microarray data and genome-wide expression profiling to the sepsis field. Four broad areas will be discussed: genome-level understanding of sepsis, biomarker discovery, gene expression-based identification of septic shock subclasses, and discovery of novel targets and pathways.

\section{Technology, approaches, and limitations}

Microarray-related technology, approaches, and limitations have been extensively reviewed elsewhere [1-5], and will be summarized below. Notably, there is now an emerging technology, RNA sequencing (RNA-Seq) [6], that has potentially intriguing applications for the field, but will not be further discussed as there are no RNA-Seq data specifically related to sepsis.

The fundamental technical innovation of microarray technology is the ability to simultaneously measure mRNA abundance of thousands of transcripts (transcriptomics). The technique generally involves reverse transcription of RNA into CDNA, with the inclusion of a labeling molecule for detection. The labeled cDNA (targets) is subsequently applied to a support surface arrayed with nucleotide sequences corresponding to specific genes (probes). The probes and targets hybridize via standard nucleic acid interactions and the amount of hybridization reflects the abundance of a specific mRNA species. The supporting surface is subsequently washed and scanned to provide raw mRNA abundance data. An important limitation of transcriptomics is that it solely provides a 'snapshot' of steady-state mRNA abundance. The degree of mRNA abundance is influenced by multiple factors, and does not provide any direct information about gene end products (proteins), nor post-translational modifiers of protein function, such as phosphorylation or glycation.

One major consideration in designing a microarray experiment involves the RNA source. Ideally, the RNA source should be relatively homogenous and closely represent the disease/condition biology of interest. For example, the discovery of neutrophil gelatinase-associated lipocalin as a biomarker for acute kidney injury included microarray-based analysis of kidneys from 
rodents subjected to renal ischemia [7]. Most of the studies described below have used the blood compartment as the RNA source. Reliance on the blood compartment has obvious limitations with regard to specific organ perturbations in clinical sepsis, but also reflects the practical limitations of tissue sampling in clinical research and does provide a broad picture of a systemic response. Blood-derived RNA can come from either whole blood (a mixed population of blood cells), or following the isolation of specific blood cells. The whole-blood approach facilitates the procurement of samples from multiple centers, without the requirement for cell separation expertise, and has the potential to provide a comprehensive picture. However, the whole blood approach has the potential to confound data interpretation due to heterogeneous blood cell populations. The cell-specific RNA approach provides a more homogenous RNA source, but has the potential to miss biologically relevant expression signatures from cells that are excluded from the experimental approach. For example, a study that focuses exclusively on peripheral blood mononuclear cells will not account for the potentially important response of neutrophils.

Another important consideration in designing a microarray experiment involves the reference (control) group to which gene expression in the population of interest will be compared. For example, if one is interested in studying gene expression patterns in sepsis, relative to a normal state, then comparisons to normal controls is appropriate. In contrast, if one is interested in discovering gene expression patterns that distinguish sepsis from 'sterile inflammation', then a more appropriate control group would consist of patients who are not infected, but meet criteria for systemic inflammatory response (SIRS).

The heterogeneity and complexity that characterize clinical sepsis present an important challenge to clinical microarray studies. From one perspective, one could say that the comprehensive nature of a microarray approach is ideally suited for studying such a heterogeneous and complex syndrome. From another perspective, the heterogeneity and complexity are potentially profound confounders for data interpretation. Accordingly, it is critical that microarray data be interpreted in the context of robust clinical/biological data that can influence gene expression patterns. These include, but are not limited to, race, gender, age, co-morbidities, infecting pathogen class, state of immune competence, and therapy.

Analysis of microarray data is an evolving and complex field. A universal initial step involves data normalization, which allows valid comparisons across samples by reducing technical variations not directly related to biological variation [5]. A typical next step involves statistical comparisons across groups of interest using either parametric or non-parametric analysis of variance. Unfortunately, there is no clear consensus as to which statistical test is most appropriate for a given data set, and it is particularly troubling that lists of 'differentially regulated genes', from the same data set, can substantially vary based on the statistical test $[8,9]$. Regardless of what statistical test one uses, it is imperative that the statistical test incorporates corrections for multiple comparisons to account for a substantially high risk of false positives. One common filter that is applied to microarray data involves an expression filter that compares mRNA abundance of specific gene probes in one cohort versus a reference cohort. Expression filters are useful to assess 'magnitude of effect' and to reduce the number of comparisons for a subsequent statistical test, but they are not valid substitutes for formal statistical testing. Finally, there is the issue of statistical power in microarray experiments, which can be calculated, but is dependent on assumptions that can be difficult to derive objectively [10]. In general, a heterogeneous study cohort will require substantially more independent samples, compared to a more homogenous cohort.

The statistical tests described above typically yield large lists of differentially regulated genes, thus leaving one with the challenge of assigning biological meaning to these gene lists. One approach to data interpretation involves the generation of 'heat maps', which statistically cluster genes and samples based on similarity of expression. Heat maps provide a broad picture of gene expression patterns and allow for the discovery of disease 'subclasses' based on differential gene expression [11]. Another approach to viewing large microarray data sets involves the generation of gene expression 'mosaics' based on a 'self-organizing map' algorithm [12,13]. These gene expression mosaics provide microarray data with a 'face' that is recognizable via intuitive pattern recognition, and were recently applied to allocate patients with septic shock into clinically relevant subclasses $[14,15]$.

Beyond these global assessments of gene expression patterns there exist a number of public and proprietary databases allowing for the assignment of biological function to gene lists. These databases examine uploaded gene lists and determine whether the gene list is enriched for genes that are biologically related, based on the established literature. The outputs from these databases range from generic (for example, 'immune response') to specific (for example, 'antigen presentation') biological processes. Furthermore, the outputs from these databases provide an estimate of significance ( $P$-values) indicating how likely a gene list is enriched for a given biological function by chance alone. The level of significance is directly proportional to the number of genes in the list that correspond to the given biological function, and indirectly proportional to the total number 
of genes in the list. A related approach to assigning biological meaning to gene lists involves the generation of gene networks based on known, direct and indirect, interactions between genes [16,17].

\section{Genome-level understanding of sepsis}

Microarray-based expression profiling has provided an unprecedented opportunity to gain a broader, genomelevel 'picture' of complex and heterogeneous clinical syndromes such as sepsis. In addition, this genome-level approach has the potential to reduce investigator bias, and thus increase discovery capability, in as much as all genes are potentially interrogated, rather than a specific set of genes chosen by the investigator based on a priori and potentially biased assumptions.

Many of the fundamental physiologic and biologic principles of the sepsis paradigms are derived from experiments involving human volunteers subjected to intravenous endotoxin challenge [18-21]. More recently, the genome-level response during experimental human endotoxemia has been studied using microarray technology [16,22,23]. Talwar and colleagues [22] compared eight volunteers challenged with intravenous endotoxin to four controls challenged with saline. Mononuclear cell-specific RNA was obtained at four different time points after endotoxin challenge and analyzed via microarray. As expected, a large number of transcripts related to inflammation and innate immunity were substantially up-regulated in response to endotoxin challenge. Interestingly, the peak transcriptomic response to the single endotoxin challenge occurred within 6 hours and mRNA levels generally returned to control levels within 24 hours. The investigators also reported endotoxinmediated differential regulation of over 100 genes not typically associated with acute inflammation (for example, cathepsin $H$, sialidase 1, UDP-glucose dehydrogenase, zinc finger protein 266, homeo box B2). Finally, and of relevance to subsequent sections of this review, endotoxin challenge also led to repression of several gene programs directly related to adaptive immunity (for example, interleukin-7 receptor, $T$ cell receptor $\alpha$ locus, zeta-chain $T$ cell receptor associated protein kinase $70 \mathrm{kDa}, \mathrm{T}$ cell receptor $\gamma$ locus).

Calvano and colleagues [16] also studied normal volunteers subjected to a single endotoxin challenge, but applied a (then) novel approach to microarray data analysis centered on knowledge-based interactive gene networks. Again, the maximal up-regulation of gene networks corresponding to inflammation and innate immunity occurred at approximately 6 hours after the endotoxin challenge, and generally returned to baseline by 24 hours. Perhaps the most interesting finding from this network-centered analysis, however, was the widespread and early repression of gene networks related to mitochondrial energy production (for example, $N A D H$ dehydrogenase 1, pyruvate dehydrogenase, ATP synthase) and protein synthesis (ribosomal protein L3, ribosomal protein S8, eukaryotic translation initiation factor). Tang and colleagues [24] have corroborated the repression of mitochondrial energy production-related genes in a study focused on neutrophil-specific gene expression in critically ill patients with sepsis.

The human endotoxemia studies described above provide a highly controlled and reproducible experimental setting to explore sepsis biology at the level of the entire transcriptome, but as with all sepsis models, this model does not fully replicate the complex and heterogeneous syndrome seen at the bedside following infection with live microbes [25]. Consequently, several investigators have attempted microarray-based studies in critically ill patients with sepsis and septic shock. These studies present considerable experimental challenges due to the inherent heterogeneity of clinical sepsis and septic shock. Nonetheless, several studies have provided novel insight into the overall genome-level response to sepsis $[9,17,24,26-34]$. A common theme across many of these studies is the massive up-regulation of inflammation- and innate immunity-related genes in patients with sepsis and septic shock. These observations are not intrinsically novel, but they are consistent with the long-standing sepsis paradigms centered on a hyperactive inflammatory response, and thus provide an important layer of biological plausibility with regard to overall microarray data output in the context of clinical sepsis.

Another common paradigm in the sepsis field involves a two-phase model consisting of an initial hyper-inflammatory phase followed by a compensatory anti-inflammatory phase, but this has been recently challenged, in large part due to the multiple failures of interventional clinical trials founded on this paradigm [35-37]. Recently, Tang and colleagues [3] conducted a formal systematic review of a carefully selected group of microarray-based human sepsis studies. A major conclusion of this systematic review is that, in aggregate, the transcriptome-level data do not consistently separate sepsis into distinct proand anti-inflammatory phases. This conclusion has been questioned [38], but is supported by several recent cytokine- and inflammatory mediator-based studies in clinical and experimental sepsis [39-41].

Another prevailing paradigm in the sepsis field involves the concept of immune-paralysis, which frames sepsis as more of an adaptive immune problem (rather than just an overactive innate immune system) and the inability to adequately clear infection $[42,43]$. Recently, this paradigm was elegantly corroborated in mice subjected to sepsis and rescued by administration of IL-7, an anti-apoptotic cytokine essential for lymphocyte survival and expansion $[44,45]$. As mentioned previously, studies in human 
volunteers challenged with endotoxin revealed early repression of gene programs related to adaptive immunity [22]. In studies focused on mononuclear cellspecific expression profiles, Tang and colleagues [30,31] have also reported early repression of adaptive immunity genes in patients with sepsis. Finally, multiple studies in children with septic shock have reported, and validated, early and persistent repression of adaptive immunityrelated gene programs (for example, genes corresponding to the $\mathrm{T}$ cell receptor) $[9,11,14,15,17,32-34]$. Thus, the concept of adaptive immune dysfunction as an early and prominent feature of clinical sepsis and septic shock seems to be well supported by the available genome-wide expression data.

Developmental age is thought to be a major contributor to sepsis heterogeneity. Recently, a microarray-based study in children with septic shock corroborated this concept at the genomic level [46]. Four developmental age groups of children were compared based on wholeblood-derived gene expression profiles. Children in the 'neonate' group ( $<28$ days of age) demonstrated a unique expression profile relative to older children. For example, children in the neonate group demonstrated widespread repression of genes corresponding to the triggering receptor expressed on myeloid cells 1 (TREM1) pathway. TREM1 is critical for amplification of the inflammatory response to microbial products and there has been recent interest in blockade of the TREM1 signaling pathway in septic shock [47]. The observation that TREM1 signaling may not be relevant in neonates with septic shock illustrates how some potential therapeutic strategies for septic shock may not have biological plausibility in certain developmental age groups.

\section{Biomarker discovery}

A daily conundrum in the intensive care unit is the ability to distinguish which patients that meet criteria for SIRS are infected, and which patients with SIRS are not infected. Accordingly, there are ongoing efforts to discover diagnostic biomarkers for sepsis (SIRS secondary to infection), and microarray approaches have the potential to enhance these efforts. Several investigators have reported genome-level signatures that can distinguish patients with SIRS from patients with sepsis $[26,29,31,48]$. A substantial amount of work, including validation, remains to be done in order to leverage these datasets into clinically applicable diagnostic biomarkers, but the datasets nonetheless provide a foundation for the derivation and development of diagnostic biomarkers for sepsis.

Investigators have also applied microarray technology to address other important clinical challenges directly related to infection. Cobb and colleagues $[49,50]$ have reported an expression signature (the 'ribonucleogram') having the potential to predict ventilator-associated pneumonia in critically ill blunt trauma patients up to 4 days before traditional clinical recognition. Similarly, Ramilo and colleagues [51] have reported expression signatures that can distinguish influenza A infection from bacterial infection, and Escherichia coli infection from Staphylococcus aureus infection, in hospitalized febrile children. In contrast, Tang and colleagues [30] were unable to define organism-specific gene expression signatures (Gram positive versus Gram negative bacteria) in critically ill adults with sepsis.

Another aspect of biomarker development in sepsis surrounds stratification biomarkers, particularly to predict outcome. Theoretically, any gene that is consistently differentially regulated between survivors and nonsurvivors in a microarray dataset may warrant further investigation as a potential outcome biomarker. For example, a microarray study by Pachot and colleagues $[27,52]$ identified CX3CR1 (fractalkine receptor) as a potential outcome biomarker in sepsis. Similarly, Nowak and colleagues [53] have leveraged microarray data to identify chemokine (C-C motif) ligand 4 (CCL4) as an outcome biomarker in children with septic shock. Both candidate stratification biomarkers, however, require further validation.

IL-8 has emerged as a robust stratification biomarker in children with septic shock [54], and the rationale for pursuing it stemmed directly from microarray-based studies identifying $I L-8$ as one of the more highly expressed genes in pediatric non-survivors of septic shock, compared to survivors [34]. Subsequent studies demonstrated that serum IL-8 protein levels, measured within 24 hours of presentation to the intensive care unit with septic shock, could predict survival in pediatric septic shock with a probability of $95 \%$ [54]. The ability of IL-8 to serve as a stratification biomarker was subsequently validated in a completely independent cohort of children with septic shock. Consequently, it has been proposed that IL-8 could be used in future pediatric septic shock interventional trials as a means to exclude patients having a high likelihood of survival with standard care, as a means of improving the risk-to-benefit ratio of a given intervention. This type of stratification strategy would be particularly applicable for an intervention that carries more than minimal risk. Interestingly, it appears that IL-8-based stratification may not perform in a similarly robust manner in adults with septic shock [55], thus providing another example of how developmental age contributes to septic shock heterogeneity.

Currently, there is an ongoing effort to derive and validate a multi-biomarker sepsis outcome risk model in pediatric septic shock. The foundation of this effort is the relatively unbiased selection of a panel of candidate outcome biomarkers using microarray data from a large cohort of children with septic shock $[56,57]$. 


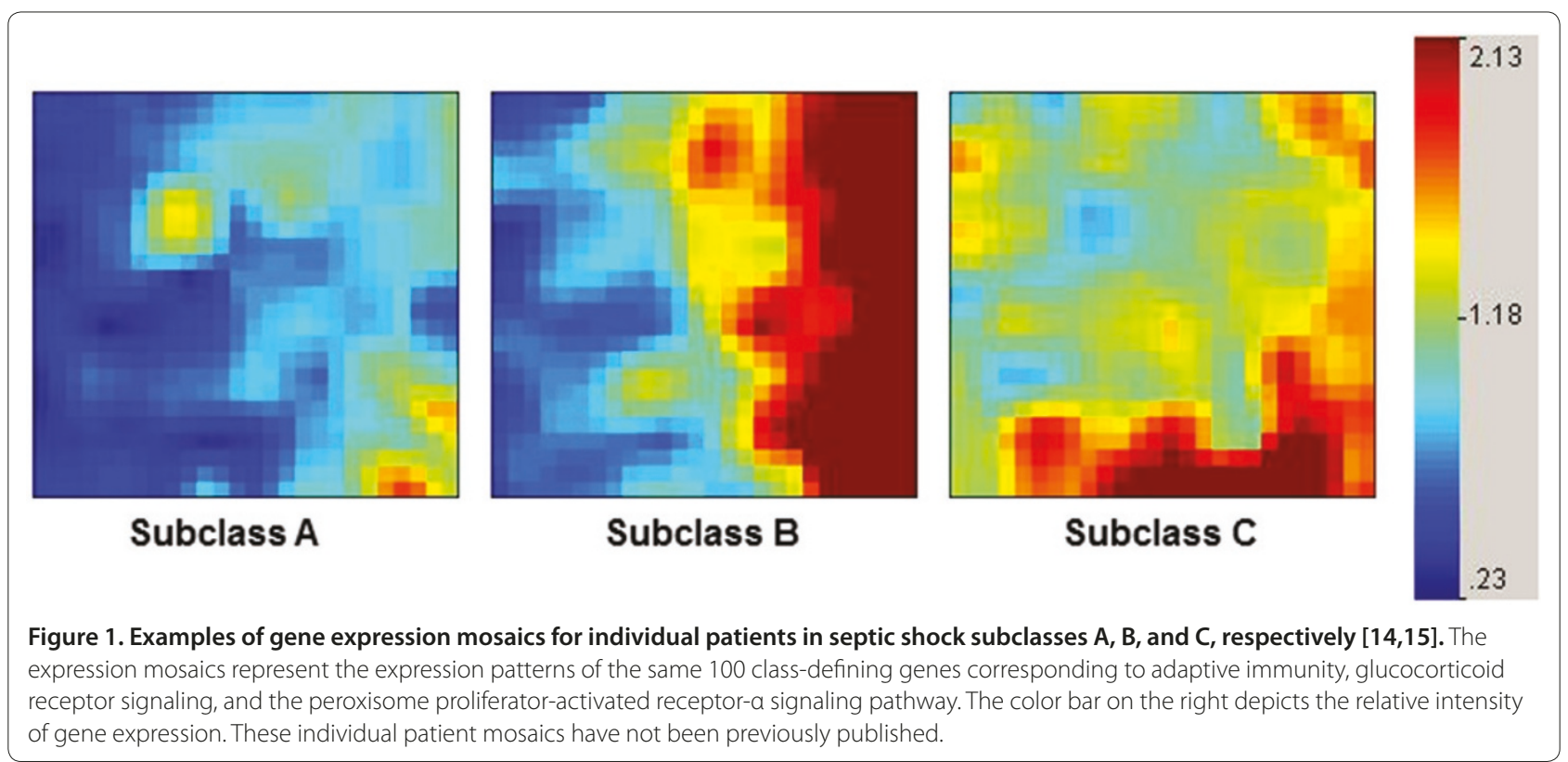

\section{Gene-expression-based identification of septic shock subclasses}

Viewing septic shock as a highly heterogeneous syndrome implies the existence of 'disease subclasses', in an analogous manner to that encountered in the oncology field [37]. Recently, there has been an attempt to identify septic shock subclasses in children based on genomewide expression profiling [11]. Complete microarray data from a large cohort of children with septic shock, representing the first 24 hours of admission, were used to identify septic shock subclasses. A heat map of over 6,000 differentially regulated genes was generated using an unsupervised clustering algorithm. Patients were then classified into one of three subclasses (subclasses 'A', 'B', or ' $C$ ') based on statistically similar gene expression patterns, as determined by the first and second order branching patterns of the heat map. Subsequently, the clinical database was mined to determine if there were any phenotypic differences between the three subclasses. Patients in subclass A had a significantly higher level of illness severity as measured by mortality, organ failure, and illness severity score.

The gene expression patterns that distinguished the subclasses were distilled to a 100-gene expression signature by conducting a leave-one-out cross-validation procedure and selecting the 100 genes having the greatest subclass prediction capability. These 100 genes were then uploaded to a gene expression database that identified enrichment for genes corresponding to adaptive immunity, glucocorticoid receptor signaling, and the peroxisome proliferator-activated receptor- $\alpha$ signaling pathway. Of note, the genes corresponding to these functional annotations were generally repressed in the subclass of patients with the higher level of illness severity (that is, subclass A patients).

In a subsequent study, the expression patterns of the 100 subclass-defining genes were depicted using visually intuitive gene expression mosaics and shown to a panel of clinicians with no formal bioinformatic training and blinded to the actual patient subclasses (Figure 1). The clinicians were able to allocate patients into the respective subclasses with a high degree of sensitivity and specificity [15]. The ability to identify a subclass of children with a higher illness severity was further corroborated when the gene-expression-based subclassification strategy was applied to a separate validation cohort of children with septic shock [14]. Collectively, these studies demonstrate the feasibility of subclassifying patients with septic shock, in a clinically relevant manner, based on the expression patterns of a discrete set of genes having relevance to sepsis biology. The availability of clinical microfluidics [58] and digital mRNA measurement technology [59] may allow for clinical feasibility of measuring the 100 class-defining genes in a timely manner that is suitable to direct patient care or for clinical trial stratification.

\section{Discovery of novel targets and pathways}

The potential to interrogate the entire genome in a relatively unbiased manner provides an opportunity to discover previously unrecognized, or unconsidered, targets and pathways relevant to sepsis biology. This is a daunting task in the context of a highly heterogeneous syndrome such as clinical sepsis, and the many unavoidable confounding factors inherent to clinical sepsis microarray studies. Nonetheless, several studies illustrate 
the potential of genome-wide expression profiling in the discovery of novel targets and pathways.

For example, using a combination of expression profiling and in vitro approaches, Pathan and colleagues [60] have identified interleukin-6 as a major contributor to myocardial depression in patients with meningococcal sepsis. This is a particularly intriguing and robust study because the study population is relatively homogeneous (that is, exclusively patients with meningococcal) compared to the majority of sepsis microarray studies that have enrolled patients with heterogeneous sepsis etiologies.

In one of the earliest clinical sepsis microarray studies, Pachot and colleagues [27] identified a set of genes differentially regulated between survivors and non-survivors. The gene most highly expressed in survivors, relative to non-survivors, was that encoding the chemokine receptor CX3CR1 (fractalkine receptor). In a subsequent validation study, these same investigators provided further evidence supporting the novel concept that dysregulation of CX3CR1 in monocytes contributes to immuneparalysis in human sepsis [52]. These studies further demonstrate the potential to discover novel pathways through discovery-oriented expression profiling.

Several studies in children with septic shock have documented early and persistent repression of gene programs directly related to zinc homeostasis, in combination with low serum zinc concentrations $[9,11,17$, 32,34]. Since normal zinc homeostasis is absolutely critical to normal immune function [61], these observations have raised the possibility of zinc supplementation as a potentially safe and low cost therapeutic strategy in clinical septic shock and other forms of critical illness [62-64]. Importantly, Knoell and colleagues [65,66] have independently corroborated that zinc supplementation is a highly beneficial strategy in experimental sepsis. Additional studies by Knoell and colleagues [67] have corroborated decreased plasma zinc concentrations in patients with sepsis, and that low plasma zinc concentrations correlate with higher illness severity. Furthermore, plasma zinc concentrations correlate inversely with monocyte expression of the zinc transporter gene SLC39A8 (also know as ZIP8) [67,68]. Interestingly, microarray-based studies in children with septic shock have reported high levels of SLC39A8 expression in nonsurvivors, relative to survivors [34]. Despite the intriguing convergence of these data from independent laboratories, the safety and efficacy of zinc supplementation in clinical sepsis remains to be directly demonstrated and is a current area of active investigation. One consideration for these studies will be the incorporation of trancriptomic analyses to determine if zinc supplementation influences the zinc-related gene repression patterns described above.
In the aforementioned studies involving children with septic shock, metalloproteinase (MMP)-8 has consistently been the highest expressed gene in patients with septic shock, relative to normal controls $[9,11,17,32-34$, 46]. In addition, MMP-8 is more highly expressed in patients with septic shock compared to patients with sepsis, and in septic shock non-survivors compared to septic shock survivors [69]. MMP-8 is also known as neutrophil collagenase because it is a neutrophil-derived protease that cleaves collagen in the extracellular matrix, but MMP-8 is also known to have other cellular sources and non-extracellular matrix substrates, including chemokines and cytokines [70]. The consistently high level of expression of MMP-8 in clinical septic shock recently stimulated the formal study of MMP-8 in experimental sepsis. These studies demonstrated that either genetic ablation of MMP-8 or pharmacologic inhibition of MMP-8 activity confers a significant survival advantage in a murine model of sepsis [69]. While these studies require further development and validation, the findings are intriguing given that there exist a number of drugs to effectively inhibit MMP-8 activity in the clinical setting [71].

\section{Conclusion}

Despite the tremendous methodological challenges that come with translational research involving humans with sepsis, microarray technology and complex bioinformatic approaches are beginning to provide novel insights into this complex syndrome. Progress, albeit slow, has been realized with regard to our understanding of the genomelevel response during sepsis, the identification of potential novel targets and pathways, discovery of candidate diagnostic and stratification biomarkers, and the possibility of clinically relevant and clinically feasible gene-expression-based subclassification. The challenges ahead include robust validation studies, standardization of technical approaches, standardization and further development of analytical algorithms, and large scale collaborations.

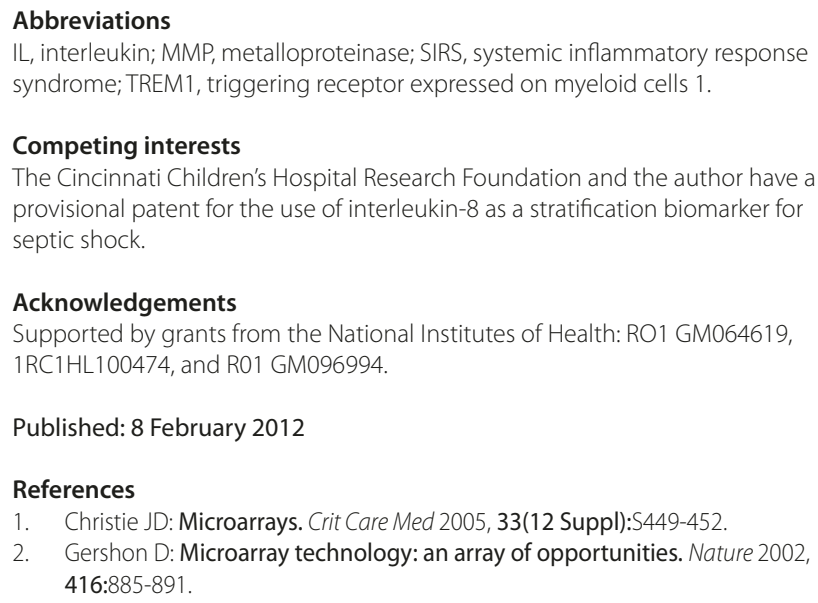

The Cincinnati Children's Hospital Research Foundation and the author have a provisional patent for the use of interleukin-8 as a stratification biomarker for septic shock.

\section{Acknowledgements}

Supported by grants from the National Institutes of Health: RO1 GM064619, 1RC1HL100474, and R01 GM096994.

Published: 8 February 2012

\section{References}

1. Christie JD: Microarrays. Crit Care Med 2005, 33(12 Suppl):S449-452.

2. Gershon D: Microarray technology: an array of opportunities. Nature 2002, 416:885-891. 
3. Tang BM, Huang SJ, McLean AS: Genome-wide transcription profiling of human sepsis: a systematic review. Crit Care 2010, 14:R237.

4. Malone JH, Oliver B: Microarrays, deep sequencing and the true measure of the transcriptome. BMC Bio/ 2011, 9:34.

5. Kim K, Zakharkin SO, Allison DB: Expectations, validity, and reality in gene expression profiling. J Clin Epidemiol 2010, 63:950-959.

6. Ozsolak F, Milos PM: RNA sequencing: advances, challenges and opportunities. Nat Rev Genet 2011, 12:87-98.

7. Mishra J, Ma Q, Prada A, Mitsnefes M, Zahedi K, Yang J, Barasch J, Devarajan P: Identification of neutrophil gelatinase-associated lipocalin as a novel early urinary biomarker for ischemic renal injury. J Am Soc Nephrol 2003, 14:2534-2543

8. Allison DB, Cui X, Page GP, Sabripour M: Microarray data analysis: from disarray to consolidation and consensus. Nat Rev Genet 2006, 7:55-65.

9. Cvijanovich N, Shanley TP, Lin R, Allen GL, Thomas NJ, Checchia P, Anas N, Freishtat RJ, Monaco M, Odoms K, Sakthivel B, Wong HR; Genomics of Pediatric SIRS/Septic Shock Investigators: Validating the genomic signature of pediatric septic shock. Physiol Genomics 2008, 34:127-134.

10. Yang MC, Yang JJ, McIndoe RA, She JX: Microarray experimental design: power and sample size considerations. Physiol Genomics 2003, 16:24-28.

11. Wong HR, Cvijanovich N, Lin R, Allen GL, Thomas NJ, Willson DF, Freishtat RJ, Anas N, Meyer K, Checchia PA, Monaco M, Odom K, Shanley TP: Identification of pediatric septic shock subclasses based on genome-wide expression profiling. BMC Med 2009, 7:34

12. Eichler GS, Huang S, Ingber DE: Gene Expression Dynamics Inspector (GEDI): for integrative analysis of expression profiles. Bioinformatics 2003, 19:2321-2322.

13. Guo Y, Eichler GS, Feng Y, Ingber DE, Huang S: Towards a holistic, yet genecentered analysis of gene expression profiles: a case study of human lung cancers. J Biomed Biotechnol 2006, 2006:69141.

14. Wong HR, Cvijanovich NZ, Allen GL, Thomas NJ, Freishtat RJ, Anas N, Meyer K, Checchia PA, Lin R, Shanley TP, Bigham MT, Wheeler DS, Doughty LA, Tegtmeyer K, Poynter SE, Kaplan JM, Chima RS, Stalets E, Basu RK, Varisco BM, Barr FE: Validation of a gene expression-based subclassification strategy for pediatric septic shock. Crit Care Med 2011, 39:2511-2517.

15. Wong HR, Wheeler DS, Tegtmeyer K, Poynter SE, Kaplan JM, Chima RS, Stalets E, Basu RK, Doughty LA: Toward a clinically feasible gene expression-based subclassification strategy for septic shock: proof of concept. Crit Care Med 2010, 38:1955-1961

16. Calvano SE, Xiao W, Richards DR, Felciano RM, Baker HV, Cho RJ, Chen RO, Brownstein BH, Cobb JP, Tschoeke SK, Miller-Graziano C, Moldawer LL, Mindrinos MN, Davis RW, Tompkins RG, Lowry SF; Inflamm and Host Response to Injury Large Scale Collab. Res. Program: A network-based analysis of systemic inflammation in humans. Nature 2005, 437:1032-1037.

17. Shanley TP, Cvijanovich N, Lin R, Allen GL, Thomas NJ, Doctor A, Kalyanaraman M, Tofil NM, Penfil S, Monaco M, Odoms K, Barnes M, Sakthivel B, Aronow BJ, Wong HR: Genome-level longitudinal expression of signaling pathways and gene networks in pediatric septic shock. Mol Med 2007, 13:495-508.

18. Boujoukos AJ, Martich GD, Supinski E, Suffredini AF: Compartmentalization of the acute cytokine response in humans after intravenous endotoxin administration. J App/ Physio/ 1993, 74:3027-3033.

19. DeLa Cadena RA, Suffredini AF, Page JD, Pixley RA, Kaufman N, Parrillo JE, Colman RW: Activation of the kallikrein-kinin system after endotoxin administration to normal human volunteers. Blood 1993, 81:3313-3317.

20. Suffredini AF, Fromm RE, Parker MM, Brenner M, Kovacs JA, Wesley RA, Parrillo $J E$ : The cardiovascular response of normal humans to the administration of endotoxin. NEngl J Med 1989, 321:280-287.

21. Suffredini AF, Harpel PC, Parrillo JE: Promotion and subsequent inhibition of plasminogen activation after administration of intravenous endotoxin to normal subjects. N Engl J Med 1989, 320:1165-1172.

22. Talwar S, Munson PJ, Barb J, Fiuza C, Cintron AP, Logun C, Tropea M, Khan S, Reda D, Shelhamer JH, Danner RL, Suffredini AF: Gene expression profiles of peripheral blood leukocytes after endotoxin challenge in humans. Physiol Genomics 2006, 25:203-215.

23. Prabhakar U, Conway TM, Murdock P, Mooney JL, Clark S, Hedge P, Bond BC, Jazwinska EC, Barnes MR, Tobin F, Damian-lordachi V, Greller L, Hurle M, Stubbs AP, Li Z, Valoret El, Erickson-Miller C, Cass L, Levitt B, Davis HM Jorkasky DK, Williams WV: Correlation of protein and gene expression profiles of inflammatory proteins after endotoxin challenge in human subjects. DNA Cell Biol 2005, 24:410-431.

24. Tang BM, MCLean AS, Dawes IW, Huang SJ, Lin RC: The use of gene-expression profiling to identify candidate genes in human sepsis. Am J Respir Crit Care Med 2007, 176:676-684.

25. Lowry SF: Human endotoxemia: a model for mechanistic insight and therapeutic targeting. Shock 2005, 24 Suppl 1:94-100.

26. Johnson SB, Lissauer M, Bochicchio GV, Moore R, Cross AS, Scalea TM: Gene expression profiles differentiate between sterile SIRS and early sepsis. Ann Surg 2007, 245:611-621.

27. Pachot A, Lepape A, Vey S, Bienvenu J, Mougin B, Monneret G: Systemic transcriptional analysis in survivor and non-survivor septic shock patients: a preliminary study. Immunol Lett 2006, 106:63-71.

28. Payen D, Lukaszewicz AC, Belikova I, Faivre V, Gelin C, Russwurm S, Launay JM, Sevenet N: Gene profiling in human blood leucocytes during recovery from septic shock. Intensive Care Med 2008, 34:1371-1376.

29. Prucha M, Ruryk A, Boriss H, Moller E, Zazula R, Herold I, Claus RA, Reinhart KA, Deigner $P$, Russwurm S: Expression profiling: toward an application in sepsis diagnostics. Shock 2004, 22:29-33.

30. Tang BM, MCLean AS, Dawes IW, Huang SJ, Cowley MJ, Lin RC: Geneexpression profiling of gram-positive and gram-negative sepsis in critically ill patients. Crit Care Med 2008, 36:1125-1128.

31. Tang BM, MCLean AS, Dawes IW, Huang SJ, Lin RC: Gene-expression profiling of peripheral blood mononuclear cells in sepsis. Crit Care Med 2009, 37:882-888.

32. Wong HR, Cvijanovich N, Allen GL, Lin R, Anas N, Meyer K, Freishtat RJ, Monaco M, Odoms K, Sakthivel B, Shanley TP; Genomics of Pediatric SIRS/ Septic Shock Investigators: Genomic expression profiling across the pediatric systemic inflammatory response syndrome, sepsis, and septic shock spectrum. Crit Care Med 2009, 37:1558-1566.

33. Wong HR, Freishtat RJ, Monaco M, Odoms K, Shanley TP: Leukocyte subsetderived genomewide expression profiles in pediatric septic shock. Pediatr Crit Care Med 2010, 11:349-355.

34. Wong HR, Shanley TP, Sakthivel B, Cvijanovich N, Lin R, Allen GL, Thomas NJ, Doctor A, Kalyanaraman M, Tofil NM, Penfil S, Monaco M, Tagavilla MA, Odoms K, Dunsmore K, Barnes M, Aronow BJ; Genomics of Pediatric SIRS/ Septic Shock Investigators: Genome-level expression profiles in pediatric septic shock indicate a role for altered zinc homeostasis in poor outcome. Physiol Genomics 2007, 30:146-155.

35. Carlet J, Cohen J, Calandra T, Opal SM, Masur H: Sepsis: time to reconsider the concept. Crit Care Med 2008, 36:964-966.

36. Marshall JC: Such stuff as dreams are made on: mediator-directed therapy in sepsis. Nat Rev Drug Discov 2003, 2:391-405.

37. Marshall JC, Vincent JL, Fink MP, Cook DJ, Rubenfeld G, Foster D, Fisher CJ, Jr, Faist E, Reinhart K: Measures, markers, and mediators: toward a staging system for clinical sepsis. A report of the Fifth Toronto Sepsis Roundtable, Toronto, Ontario, Canada, October 25-26, 2000. Crit Care Med 2003, 31:1560-1567.

38. Russell JA: Gene expression in human sepsis: what have we learned? Crit Care 2011, 15:121.

39. Gogos CA, Drosou E, Bassaris HP, Skoutelis A: Pro- versus anti-inflammatory cytokine profile in patients with severe sepsis: a marker for prognosis and future therapeutic options. J Infect Dis 2000, 181:176-180.

40. Osuchowski MF, Welch K, Siddiqui J, Remick DG: Circulating cytokine/ inhibitor profiles reshape the understanding of the SIRS/CARS continuum in sepsis and predict mortality. J Immunol 2006, 177:1967-1974.

41. Osuchowski MF, Welch K, Yang H, Siddiqui J, Remick DG: Chronic sepsis mortality characterized by an individualized inflammatory response. J Immunol 2007, 179:623-630

42. Hotchkiss RS, Karl IE: The pathophysiology and treatment of sepsis. N EnglJ Med 2003, 348:138-150

43. Hotchkiss RS, Opal S: Immunotherapy for sepsis - a new approach against an ancient foe. N Engl J Med 2010, 363:87-89.

44. Unsinger J, McGlynn M, Kasten KR, Hoekzema AS, Watanabe E, Muenzer JT, McDonough JS, Tschoep J, Ferguson TA, McDunn JE, Morre M, Hildeman DA, Caldwell CC, Hotchkiss RS: IL-7 promotes T cell viability, trafficking, and functionality and improves survival in sepsis. J/mmuno/ 2010 184:3768-3779.

45. Kasten KR, Prakash PS, Unsinger J, Goetzman HS, England LG, Cave CM, Seitz AP, Mazuski CN, Zhou TT, Morre M, Hotchkiss RS, Hildeman DA, Caldwell CC: Interleukin-7 (IL-7) treatment accelerates neutrophil recruitment through gamma delta T-cell IL-17 production in a murine model of sepsis. Infect Immun 2010, 78:4714-4722

46. Wynn JL, Cvijanovich NZ, Allen GL, Thomas NJ, Freishtat RJ, Anas N, Meyer K, 
Checchia PA, Lin R, Shanley TP, Bigham MT, Banschbach S, Beckman E, Wong HR: The influence of developmental age on the early transcriptomic response of children with septic shock. Mol Med 2011 [Epub ahead of print].

47. Bouchon A, Facchetti F, Weigand MA, Colonna M: TREM-1 amplifies inflammation and is a crucial mediator of septic shock. Nature 2001, 410:1103-1107.

48. Lissauer ME, Johnson SB, Bochicchio GV, Feild CJ, Cross AS, Hasday JD, Whiteford CC, Nussbaumer WA, Towns M, Scalea TM: Differential expression of toll-like receptor genes: sepsis compared with sterile inflammation 1 day before sepsis diagnosis. Shock 2009, 31:238-244.

49. Cobb JP, Moore EE, Hayden DL, Minei JP, Cuschieri J, Yang J, Li Q, Lin N, Brownstein BH, Hennessy L, Mason PH, Schierding WS, Dixon DJ, Tompkins RG, Warren HS, Schoenfeld DA, Maier RV: Validation of the riboleukogram to detect ventilator-associated pneumonia after severe injury. Ann Surg 2009, 250:531-539.

50. McDunn JE, Husain KD, Polpitiya AD, Burykin A, Ruan J, Li Q, Schierding W, Lin N, Dixon D, Zhang W, Coopersmith CM, Dunne WM, Colonna M, Ghosh BK, Cobb JP: Plasticity of the systemic inflammatory response to acute infection during critical illness: development of the riboleukogram. PLOS One 2008, 3:e1564

51. Ramilo O, Allman W, Chung W, Mejias A, Ardura M, Glaser C, Wittkowski KM, Piqueras B, Banchereau J, Palucka AK, Chaussabel D: Gene expression patterns in blood leukocytes discriminate patients with acute infections. Blood 2007, 109:2066-2077.

52. Pachot $A$, Cazalis MA, Venet F, Turrel F, Faudot $C$, Voirin N, Diasparra J, Bourgoin N, Poitevin F, Mougin B, Lepape A, Monneret G: Decreased expression of the fractalkine receptor $\mathrm{CX} 3 \mathrm{CR} 1$ on circulating monocytes as new feature of sepsis-induced immunosuppression. J Immunol 2008, 180:6421-6429.

53. Nowak JE, Wheeler DS, Harmon KK, Wong HR: Admission chemokine (C-C motif) ligand 4 levels predict survival in pediatric septic shock. Pediatr Crit Care Med 2010, 11:213-216.

54. Wong HR, Cvijanovich N, Wheeler DS, Bigham MT, Monaco M, Odoms K, Macias WL, Williams MD: Interleukin-8 as a stratification tool for interventional trials involving pediatric septic shock. Am J Respir Crit Care Med 2008, 178:276-282.

55. Calfee CS, Thompson BT, Parsons PE, Ware LB, Matthay MA, Wong HR: Plasma interleukin- 8 is not an effective risk stratification tool for adults with vasopressor-dependent septic shock. Crit Care Med 2010, 38:1436-1441.

56. Kaplan JM, Wong HR: Biomarker discovery and development in pediatric critical care medicine. Pediatr Crit Care Med 2011, 12:165-173.

57. Standage SW, Wong HR: Biomarkers for pediatric sepsis and septic shock. Expert Rev Anti Infect Ther 2011, 9:71-79.

58. Kotz KT, Xiao W, Miller-Graziano C, Qian WJ, Russom A, Warner EA, Moldawer LL, De A, Bankey PE, Petritis BO, Camp DG 2nd, Rosenbach AE, Goverman J, Fagan SP, Brownstein BH, Irimia D, Xu W, Wilhelmy J, Mindrinos MN, Smith RD, Davis RW, Tompkins RG, Toner M; Inflammation and the Host Response to
Injury Collaborative Research Program: Clinical microfluidics for neutrophil genomics and proteomics. Nat Med 2010, 16:1042-1047.

59. Geiss GK, Bumgarner RE, Birditt B, Dahl T, Dowidar N, Dunaway DL, Fell HP, Ferree S, George RD, Grogan T, James JJ, Maysuria M, Mitton JD, Oliveri P,

Osborn JL, Peng T, Ratcliffe AL, Webster PJ, Davidson EH, Hood L, Dimitrov K: Direct multiplexed measurement of gene expression with color-coded probe pairs. Nat Biotechnol 2008, 26:317-325.

60. Pathan N, Hemingway CA, Alizadeh AA, Stephens AC, Boldrick JC, Oragui EE, McCabe C, Welch SB, Whitney A, O'Gara P, Nadel S, Relman DA, Harding SE, Levin M: Role of interleukin 6 in myocardial dysfunction of meningococcal septic shock. Lancet 2004, 363:203-209.

61. Rink L, Haase H: Zinc homeostasis and immunity. Trends Immunol 2007, 28:1-4.

62. Cvijanovich NZ, King JC, Flori HR, Gildengorin G, Wong HR: Zinc homeostasis in pediatric critical illness. Pediatr Crit Care Med 2009, 10:29-34.

63. Heyland DK, Jones N, Cvijanovich NZ, Wong H: Zinc supplementation in critically ill patients: a key pharmaconutrient? J Parenter Enteral Nutr 2008, 32:509-519.

64. Weitzel LR, Mayles WJ, Sandoval PA, Wischmeyer PE: Effects of pharmaconutrients on cellular dysfunction and the microcirculation in critical illness. Curr Opin Anaesthesiol 2009, 22:177-183.

65. Bao S, Liu MJ, Lee B, Besecker B, Lai JP, Guttridge DC, Knoell DL: Zinc modulates the innate immune response in vivo to polymicrobial sepsis through regulation of NF-kappaB. Am J Physiol Lung Cell Mol Physiol 2010, 298:L744-754.

66. Knoell DL, Julian MW, Bao S, Besecker B, Macre JE, Leikauf GD, DiSilvestro RA, Crouser ED: Zinc deficiency increases organ damage and mortality in a murine model of polymicrobial sepsis. Crit Care Med 2009, 37:1380-1388.

67. Besecker BY, Exline MC, Hollyfield J, Phillips G, Disilvestro RA, Wewers MD, Knoell DL: A comparison of zinc metabolism, inflammation, and disease severity in critically ill infected and noninfected adults early after intensive care unit admission. Am J Clin Nutr 2011, 93:1356-1364.

68. Knoell DL, Liu MJ: Impact of zinc metabolism on innate immune function in the setting of sepsis. Int J Vitam Nutr Res 2010, 80:271-277.

69. Solan PD, Dunsmore KE, Denenberg AG, Odom K, Zingarelli B, Wong HR: A novel role for matrix metalloproteinase-8 in sepsis. Crit Care Med 2011 [Epub ahead of print].

70. Van Lint P, Libert C: Matrix metalloproteinase-8: cleavage can be decisive. Cytokine Growth Factor Rev 2006, 17:217-223.

71. Vanlaere I, Libert C: Matrix metalloproteinases as drug targets in infections caused by gram-negative bacteria and in septic shock. Clin Microbiol Rev 2009, 22:224-239.

doi:10.1186/cc10537

Cite this article as: Wong HR: Clinical review: Sepsis and septic shock - the potential of gene arrays. Critical Care 2012, 16:204. 